\title{
Pertumbuhan dan Perkembangan Eksplan Rumput Laut Gracilaria verrucosa dan Gracilaria gigas pada Aklimatisasi di Tambak
}

\author{
Sri Redjeki Hesti Mulyaningrum*, Andi Parenrengi dan Emma Suryati \\ Balai Penelitian dan Pengembangan Budidaya Air Payau \\ Jl. Makmur Dg. Sitakka No. 129, Maros, Sulawesi Selatan 90512 Indonesia \\ Telp (0411) 371544; Fax (0411) 371545 \\ Email: titut_suryanto@yahoo.com
}

\begin{abstract}
Abstrak
Aklimatisasi eksplan rumput laut hasil kultur jaringan merupakan proses adaptasi eksplan dengan lingkungan budidaya. Penelitian ini bertujuan untuk mengevaluasi performa pertumbuhan dan perkembangan eksplan rumput laut G. verrucosa dan G. gigas yang diaklimatisasi di tambak dan mendapatkan informasi awal mengenai prospek pengembangan budidaya rumput laut G. gigas di tambak. Eksplan rumput laut G. verrucosa dan G. gigas hasil kultur jaringan dipelihara dalam hapa berukuran 50x50x50 cm dengan berat awal $15 \mathrm{~g}^{. h a p a-1}$ dan dipelihara di tambak. Desain penelitian adalah rancangan acak lengkap (RAL) dengan enam unit penelitian terdiri dari tiga ulangan untuk masing-masing spesies. Pemeliharaan eksplan dilakukan selama 60 hari dan setiap 15 hari dilakukan pengukuran bobot, panjang dan perkembangan eksplan serta monitoring terhadap kualitas air. Pengamatan histologi sel rumput laut G. verrucosa dan G. gigas dilakukan dibawah mikroskop. Analisis data pertumbuhan dilakukan dengan uji komparatif independent t-test sedangkan data perkembangan eksplan dan histologi sel rumput laut dianalisis secara deskritif. Pada pemeliharaan di tambak kedua jenis rumput laut memiliki pertumbuhan yang berbeda nyata $(P<0,05)$. Rumput laut $G$. verrucosa memiliki bobot mutlak lebih tinggi (221,82 g) dari G. gigas (51,94 g) dan LPH (laju pertumbuhan harian) bobot lebih tinggi $(3,27 \%)$ dari G. gigas (2\%). Rumput laut G. verrucosa juga memiliki pertambahan panjang yang lebih tinggi $(5,28$ $\mathrm{cm})$ dari G. gigas $(2,71 \mathrm{~cm})$ dengan LPH panjang masing-masing sebesar 3,06\% dan 2,18\%. Perkembangan eksplan rumput laut G. verrucosa lebih cepat daripada G. gigas karena faktor fisika dan kimia lingkungan perairan tambak yang tidak sesuai untuk pertumbuhan rumput laut G. gigas yang memiliki susunan sel korteks lebih rapat.
\end{abstract}

Kata kunci: pertumbuhan, perkembangan, G. verrucosa, G. gigas, eksplan, tambak

\begin{abstract}
Growth and Development of Seaweed Explants Gracilaria verrucosa and Gracilaria gigas on Pond Acclimatization
\end{abstract}

Acclimatization of tissue culture seaweed explants was an adaptation procces of explants to cultivation environment. This study aims to evaluate the growth and development of G. verrucosa dan G. gigas explants on pond acclimatization as early information of pond aquaculture development of G. gigas. Explants of G. verrucosa and G. gigas were rearing on $50 \times 50 \times 50 \mathrm{~cm}$ cage net with 15 g.cage $\mathrm{e}^{-1}$ of initial weight and cutured on pond. The study was a completely randomized design with six unit experiment including three replicates for each species. Acclimation was done in 60 days then explants weight, length, development, and water quality were monitored every 15 days. G. verrucosa and G. gigas cell histology was observed under microscope. Growth data was analyzed comparatively using independent t-test then explants development and cell histology were represented descriptively. The study showed that the growth of both species was significantly different $(P<0.05)$ on pond cultivation. G. verrucosa had higher weight (221.82 g) than G. gigas (51.94 g) also higher DGR (daily growth rate) (3.27\%) than G. gigas (2\%). G. verrucosa also had higher elongation $(5.28 \mathrm{~cm})$ than $\mathrm{G}$. gigas $(2.71 \mathrm{~cm})$ with length DGR of $3.06 \%$ and $2.18 \%$, respectively. The development of G. verrucosa explants was better than G. gigas, because of the physical and chemical environment of pond water was not suitable for G. gigas which had dense cortical structure.

Keywords: growth, development, G. verrucosa, G. gigas, explants, pond 


\section{Pendahuluan}

Rumput laut Gracilaria merupakan golongan alga merah penghasil agar (agarofit) dan merupakan rumput laut yang menjadi prioritas dikembangkan selain Laminaria japonica, Undaria pinnatifida, Porphyra, Eucheuma dan Kappaphycus (Lüning dan Pang, 2003; FAO, 2014). Pemanfaatan rumput laut Gracilaria sangat luas sebagai bahan baku industri, sehingga budidaya rumput laut Gracilaria banyak dikembangkan di Indonesia, termasuk spesies $G$. verrucosa dan $\mathrm{G}$. gigas.

Gracilaria merupakan spesies rumput laut yang mengalami peningkatan produksi dari tahun 1990 hingga 2010 (FAO, 2012), namun permintaan pasar dunia terhadap rumput laut ini terus meningkat hingga 3-5\% tiap tahun (Bixler dan Porse, 2011). Intensifikasi budidaya Gracilaria terus digalakkan untuk mencukupi kebutuhan industri, salah satunya dengan memperluas kawasan produksi. Rumput laut $G$. gigas lebih banyak dibudidayakan di laut, namun budidaya di tambak saat ini mulai dilakukan sebagai salah satu upaya meningkatkan produksi melalui perluasan kawasan. Sedangkan G. verrucosa lebih banyak dibudidayakan di tambak karena dapat hidup pada perairan bersalinitas 15-30 ppt (Anggadiredja et al., 2007).

Upaya peningkatan produksi juga dilakukan melalui penyediaan bibit dengan teknik setting spora (Yudiati et al., 2004) atau dengan kultur jaringan. Mikropropagasi kultur jaringan banyak digunakan untuk propagasi klon dalam skala besar untuk mendapatkan berbagai sifat unggul tertentu dari tanaman (Reddy et al., 2008). Salah satu metode yang sering digunakan adalah kultur talus, dimana propagasi dimulai di laboratorium dan kemudian dikembangkan secara massal di lingkungan budidaya dengan terlebih dahulu melalui proses aklimatisasi.

Metode ini merupakan metode vegetatif dengan fragmentasi langsung dan pemotongan talus yang sering digunakan pada perbanyakan makro alga baik pada skala budidaya maupun laboratorium (Yokoya et al., 2003; Skurzynski dan Bocia, 2011; Yong et al., 2013; Mulyaningrum et al., 2014). Penyediaan bibit rumput laut $G$. verrucosa dan G. gigas melalui kultur jaringan dengan aklimatisasi di tambak telah dilakukan, namun studi mengenai perkembangan eksplan rumput laut $G$. verrucosa dan $G$. gigas pada pemeliharaan di tambak masih sangat terbatas.

Penelitian ini bertujuan untuk mengevaluasi performa pertumbuhan dan perkembangan eksplan rumput laut G. verrucosa dan G. gigas yang diaklimatisasi di tambak dan mendapatkan informasi awal mengenai prospek pengembangan budidaya rumput laut $\mathrm{G}$. gigas di tambak.

\section{Materi dan Metode}

Penelitian dilaksanakan di tambak percobaan desa Taipa kabupaten Takalar. Eksplan rumput laut G. verrucosa dan G. gigas hasil kultur jaringan dipelihara dalam hapa berukuran $50 \times 50 \times 50 \mathrm{~cm}$ dengan berat awal 15 g.hapa-1. Hapa diikat pada pancang bambu dengan ketinggian $\pm 15 \mathrm{~cm}$ diatas dasar tambak. Pemeliharaan eksplan dilaksanakan selama 60 hari. Pada 30 hari pertama digunakan hapa berwarna hijau yang memiliki ukuran mesh $\pm 0,5 \mathrm{~mm}$ agar eksplan yang masih berukuran kecil dapat terlindungi dengan baik. Pada 30 hari kedua digunakan hapa berwarna hitam yang memiliki ukuran mesh $\pm 4,5 \mathrm{~mm}$ agar eksplan yang sudah mulai berkembang mendapatkan sirkulasi air dan nutrien yang baik (Gambar 1).

Setiap 15 hari dilakukan pengukuran bobot, panjang eksplan dari pangkal hingga ujung tunas serta monitoring terhadap kualitas air. Laju pertumbuhan bobot harian (LPH bobot) dihitung menggunakan rumus berikut (Dawes et al., 1993):

$$
\text { LPH bobot }(\%)=\frac{\operatorname{lnWt} / \text { Wo }}{t} \times 100
$$

dimana: $W t=$ bobot bibit(g) pada t hari

Wo $=$ bobot awal bibit (g)

$\mathrm{t}=$ masa pemeliharaan

Laju pertumbuhan panjang harian (LPH panjang) dihitung menggunakan rumus berikut (Rueness dan Tananger, 1984):

$$
\text { LPH panjang }(\%)=\frac{\operatorname{lnLt} / \text { Lo }}{t} \times 100
$$

dimana: $\quad$ Lt $=$ panjang bibit (g) pada t hari

Lo $=$ panjang awal bibit $(g)$

$\mathrm{t}=$ masa pemeliharaan

Desain penelitian adalah rancangan acak lengkap (RAL) dengan enam unit penelitian terdiri dari tiga ulangan untuk setiap spesies rumput laut. Pengamatan perkembangan eksplan dilakukan dengan mengambil gambar menggunakan kamera, sedangkan sel talus rumput laut diamati dibawah mikroskop Olympus IX71 untuk mengetahui susunan sel talus rumput laut kedua spesies. 


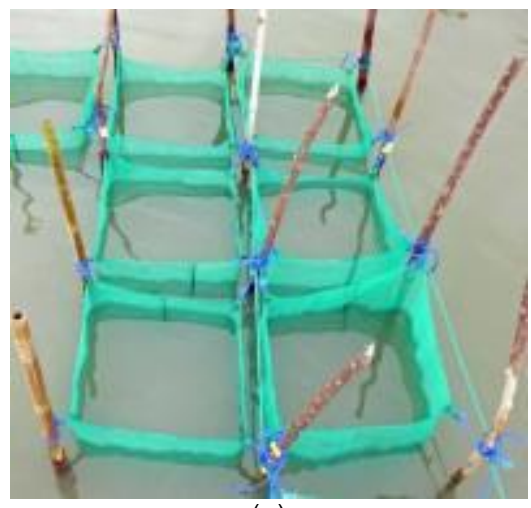

(a)

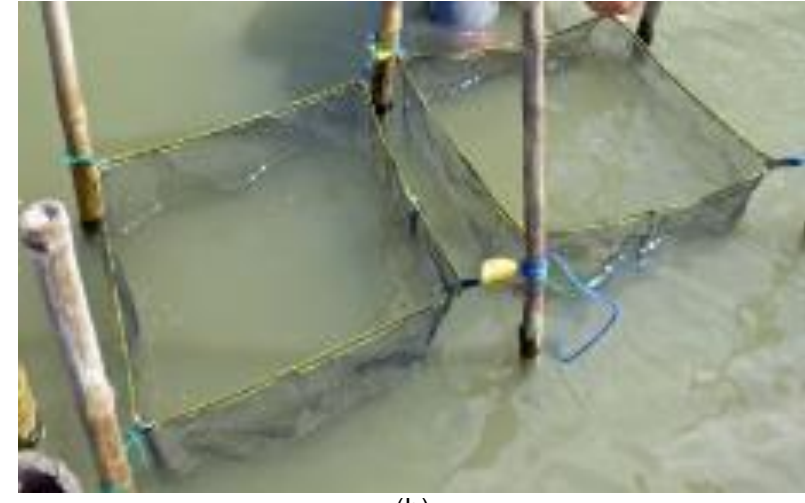

(b)

Gambar 1. Aklimatisasi eksplan rumput laut G. verrucosa dan G. gigas menggunakan hapa berukuran mesh $0,5 \mathrm{~mm}$ pada awal-30 hari masa aklimatisasi (a); dan happa berukuran mesh 4,5 mm pada 30-60 hari masa aklimatisasi (b).

Analisis data pertumbuhan dilakukan dengan uji komparasi independent t-test, sedangkan perkembangan eksplan dan histologi sel rumput laut dianalisis secara deskriptif.

\section{Hasil dan Pembahasan}

\section{Pertumbuhan eksplan}

Hasil pengamatan memperlihatkan bahwa eksplan dari kedua spesies mengalami peningkatan bobot selama aklimatisasi. Eksplan kedua species dapat tumbuh di tambak, namun terdapat perbedaan pola pertumbuhan eksplan rumput laut G. verrucosa dan G. gigas, dimana eksplan $G$. verrucosa memiliki bobot mutlak yang lebih tinggi (221,82 g) daripada G. gigas (51,94 g) (Gambar 2.).

Terdapat perbedaan bobot mutlak yang signifikan antara eksplan G. verrucosa dan G. gigas $(P=0,000)$. Peningkatan bobot mengindikasikan bahwa eksplan dapat beradaptasi dengan kondisi lingkungan perairan tambak yang mendukung untuk pertumbuhan.

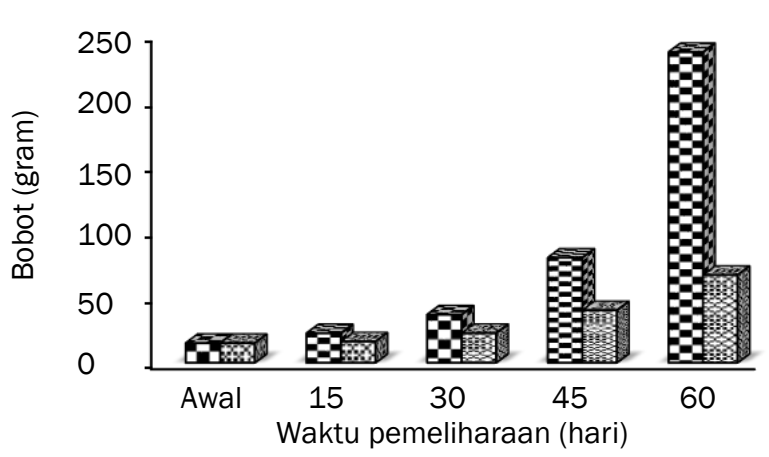

Gambar 2. Bobot eksplan rumput laut G. verrucosa dan G. gigas selama aklimatisasi. Keterangan: $\mathbf{\nexists}=\mathrm{G}$. verrucosa, 閶 = G. gigas
G. verucosa memiliki kemampuan beradaptasi dengan lingkungan perairan tambak yang lebih baik daripada G. gigas, hal ini terlihat dari hasil pengukuran LPH bobot eksplan dimana rumput laut $G$. verrucosa memiliki LPH bobot yang lebih tinggi $(3,27 \%)$ daripada G. gigas $(2 \%)$. Terdapat perbedaan yang signifikan antara LPH bobot $G$. verrucossa dan G. gigas $(P=0,000)$. Selama aklimatisasi di tambak, LPH eksplan rumput laut G. verrucosa berada pada kisaran 2,09-3,27\%, dan G. gigas pada kisaran 1,61-2\% (Gambar 3). Hasil penelitian sebelumnya memberikan informasi bahwa LPH untuk G. verrucosa berkisar 1,59-4,95\% dan G. chorda pada kisaran 0,91-4,47\% (Choi et al., 2006); Gracilaria spp. pada kisaran $10-12 \%$ dan 10,5\% (Ren et al., 1984; Hurtado-Ponce, 1990).

Peningkatan bobot eksplan terjadi karena talus semakin membesar dan peningkatan jumlah tunas, selain itu juga terjadi peningkatan panjang eksplan. Peningkatan panjang eksplan rumput laut

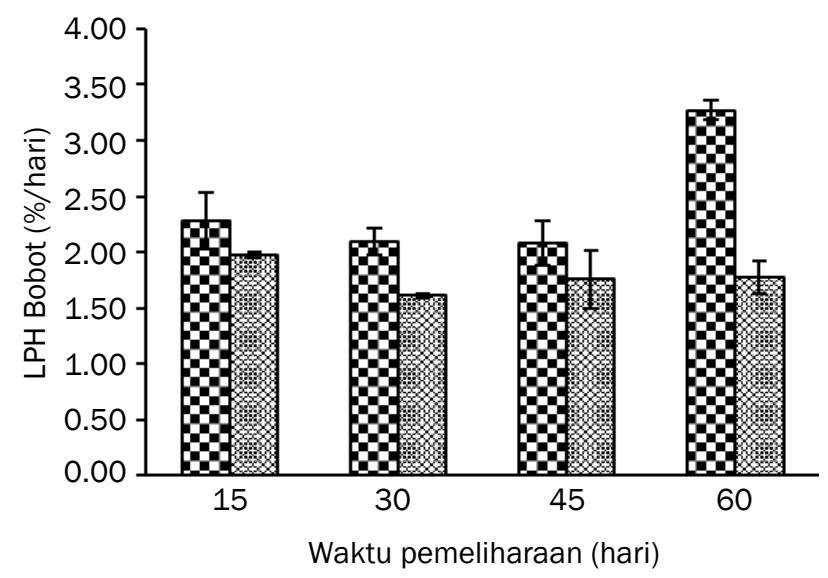

Gambar 3. Laju pertumbuhan bobot harian rumput laut G. verrucosa dan $G$. gigas selama aklimatisasi. Keterangan: $\mathbf{Z}=$ G. verrucosa, 閶 $=$ G. gigas 
G. verrucosa pada kisaran 1,22-5,28 cm sedangkan G. gigas pada kisaran 0,58-2,71 cm (Gambar 4). G. verrucosa memiliki LPH panjang lebih tinggi (3,06\%) daripada G. gigas $(2,18 \%)$ (Gambar 5). Hasil analisis komparatif uji t memperlihatkan bahwa LPH panjang kedua spesies rumput laut berbeda nyata $(P=0,000)$.

Menurut Yong et al. (2014), suatu organisme bila dipindahkan ke habitat baru akan melakukan penyesuaian diri terhadap kondisi lingkungan baru, rumput laut yang cepat menyesuaikan diri dengan lingkungan barunya akan mampu tumbuh dengan cepat, sehingga pertumbuhan optimal. Perbedaan pertumbuhan eksplan G. verrucosa dan G. gigas terjadi karena adanya perbedaan kemampuan beradaptasi pada lingkungan tambak. Habitat rumput laut. G. verrucosa lebih banyak di dekat pantai pada kedalaman 1-2 $\mathrm{m}$ dan tumbuh baik pada tanah yang memiliki komposisi pasir dan lumpur, sedangkan $G$. gigas tumbuh baik di perairan muara yang tenang dengan komposisi dasar pasir dan batu.

Rumput laut G. verrucosa dapat tumbuh pada kisaran salinitas yang lebar yakni 5-35 ppt, dan tumbuh optimal pada 15-30 ppt (Ohmi, 1958; Choi, 2006). Rumput laut G. verrucosa lebih banyak dibudidayakan di tambak sedangkan G. gigas lebih banyak dibudidayakan di laut, kondisi ini diduga menjadi alasan mengapa respon pertumbuhan rumput laut G. verrucosa lebih baik dari G. gigas pada pemeliharaan di tambak. Budidaya rumput laut pada lingkungan yang berbeda akan menghasilkan produktivitas yang berbeda. Menurut Diana et al. (2014), produktivitas rumput laut G. gigas yang dibudidayakan di laut lebih tinggi daripada budidaya di tambak.

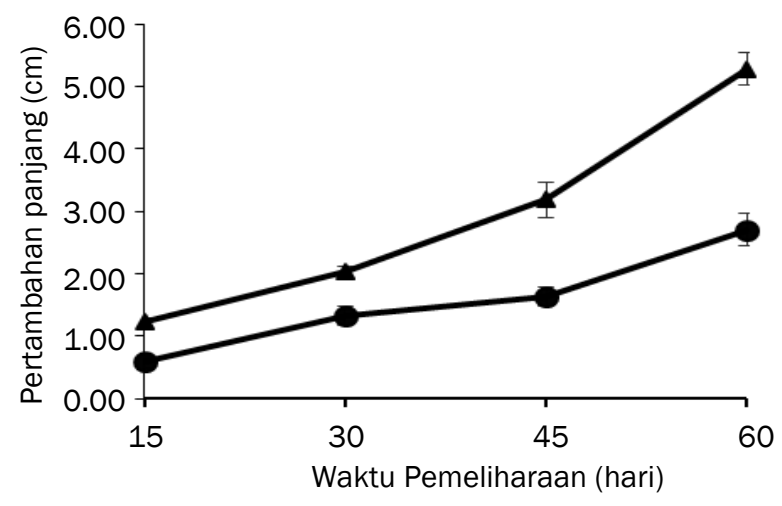

Gambar 4. Pertambahan panjang rumput laut $G$. verrucosa dan $G$. gigas selama aklimatisasi. Keterangan : $-\leftarrow=$ G. verrucosa, $-0=\mathrm{G}$. gigas

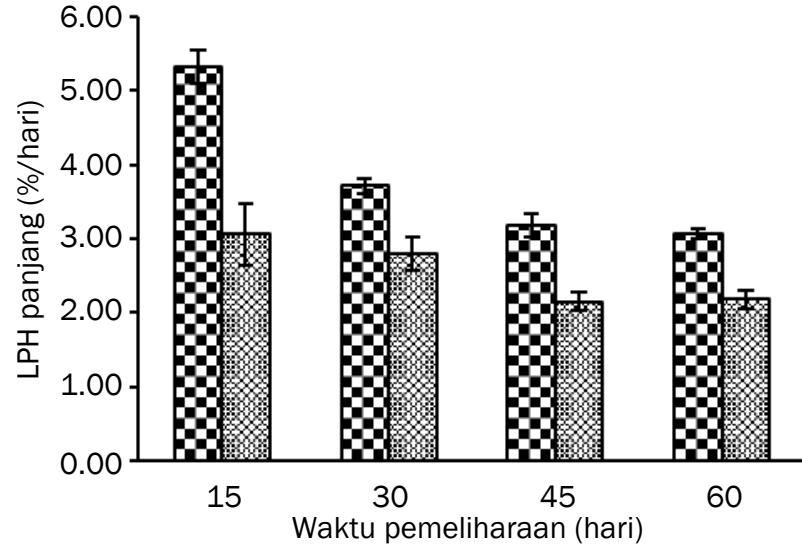

Gambar 5. Laju pertumbuhan panjang harian rumput laut G. verrucosa dan G. gigas selama pemeliharaan. Keterangan: $\mathbf{\Xi}=\mathrm{G}$. verrucosa, 閧 $=$ G. gigas

\section{Perkembangan eksplan}

Eksplan rumput laut G. verrucosa berkembang lebih cepat daripada G. gigas. Lihat Gambar 6. Pada awal pemeliharaan, eksplan kedua spesies dari laboratorium memiliki tunas apikal. Pada hari ke-15 eksplan rumput laut G. verrucosa mulai tumbuh cabang lateral pada tunas apikal, kemudian pada hari ke-30 percabangan lateral tersebut mulai berkembang. Percabangan talus semakin banyak pada hari ke-45 hingga hari ke-60 sehingga eksplan berkembang menjadi rumpun rumput laut

Perkembangan eksplan G. gigas memiliki perbedaan dengan G. verrucosa, dimana eksplan G. gigas cenderung memiliki tunas apikal saja dari awal hingga hari ke-60. Tunas apikal pada eksplan G. gigas cenderung terus bertambah panjang hingga hari ke-60 dan tidak membentuk percabangan lateral. Selain itu percabangan talus pada eksplan G. gigas cenderung tidak berubah dari hari ke-15 hingga hari ke-60 masa aklimatisasi.

Aklimatisasi merupakan proses yang penting dimana rumput laut hasil kultur jaringan secara perlahan menyesuaikan dengan perubahan lingkungan seperti suhu, kelembaban, fotoperiode dan $\mathrm{pH}$. Kesuksesan proses aklimatisasi merupakan kunci penting untuk industri kultur jaringan rumput laut. Pemeliharaan rumput laut hasil kultur jaringan tanpa proses aklimatisasi dapat menyebabkan kematian rumput laut karena akan mengalami stres akibat perubahan kondisi lingkungan yang mendadak (Yong et al., 2014). 


\section{Struktur sel}

Pertumbuhan dan perkembangan suatu tanaman sangat dipengaruhi oleh kondisi susunan sel tanaman tersebut, susunan sel mempengaruhi proses difusi nutrien, air dan mineral yang diperlukan untuk melakukan ekspansi pertumbuhan tanaman (Ortega, 2010). Susunan sel G. gigas lebih rapat dan lebih teratur dibandingkan susunan sel $G$. verrucosa. Pada Tabel 1. terlihat bahwa sel medula rumput laut $G$. verrucosa memiliki susunan yang tidak teratur, berbentuk lonjong dan banyak terdapat ruang yang kosong antar sel. Sel korteks pada G. verrucosa memiliki susunan yang kurang rapat. Sel medula rumput laut $G$. gigas memiliki susunan sel yang teratur dan rapat, susunan sel korteks juga lebih rapat dan teratur.

Menurut Ohmi (1958), G. verrucosa memiliki 2-3 lapisan korteks dimana transisi medula dan korteks memiliki susunan yang acak. Sel-sel medula rumput laut G. gigas terdiri dari 5-8 lapisan tidak berpigmen, merupakan sel-sel sperikal dengan vacuola dan sel-selnya dapat meningkat hingga mencapai ukuran diameter $600 \mu \mathrm{m}$, bagian korteks tersusun dari sel globular dengan sitoplasma yang padat (Terada dan Ohno, 2000).

Susunan sel kedua spesies (Tabel 1.) dapat menjelaskan perbedaan pertumbuhan dan perkembangan eksplan G. verrucosa dan G. gigas pada pemeliharan di tambak. Faktor fisika dan kimia lingkungan perairan sangat berperan bagi pertumbuhan rumput laut. Salah satu faktor fisika yang mempengaruhi pertumbuhan rumput laut adalah pergerakan arus. Rumput laut G. gigas memiliki susunan sel korteks yang lebih rapat dibandingkan G. verrucosa sehingga spesies ini memerlukan stimulasi gerakan arus air yang lebih kuat untuk membantu proses osmosis nutrien ke dalam sel yang diperlukan untuk pertumbuhan dan perkembangan sel. Berbeda dengan susunan sel korteks G. verrucosa yang terlihat tidak padat sehingga nutrien dan air mudah masuk dengan pergerakan air yang rendah. Kondisi perairan tambak memiliki pergerakan air yang rendah sehingga lebih cocok untuk rumput laut $\mathrm{G}$. verrucosa daripada G. gigas.

Lingkungan perairan laut yang memiliki arus yang kuat lebih cocok untuk rumput laut $G$. gigas. Pada budidaya di laut, rumput laut G. gigas mendapatkan tekanan pasang surut dan arus serta respon terhadap cahaya yang mengakibatkan pembesaran sel dan pertumbuhan lebih baik dari budidaya di tambak yang cenderung ke arah reproduktif dengan memperbanyak sel generatif (Dawes et al., 1981; Kadi dan Atmadja, 1988).

Susunan sel korteks rumput laut G. gigas yang lebih rapat juga memerlukan lingkungan perairan dengan salinitas yang tinggi agar membran sel mendapatkan tekanan osmosis yang lebih tinggi untuk proses transport nutrien. Salinitas air tambak selama penelitian berada pada kisaran 2-16 ppt, pada kisaran salinitas ini rumput laut G. verrucosa masih dapat tumbuh. Dengan kisaran salinitas tersebut $G$. verrucosa memiliki pertumbuhan dan perkembangan yang lebih baik daipada G. gigas karena G. verrucosa memiliki susunan sel korteks yang tidak rapat sehingga pada salinitas yang rendah proses transport nutrien masih dapat berjalan dengan baik, hal sebaliknya terjadi pada $G$. gigas. Menurut Lobban dan Harrison (1994) dan Choi et al. (2010), salinitas sangat berperan dalam pertumbuhan dan morfogenetik rumput laut karena terkait dalam proses osmoregulasi sel.

Apabila salinitas sesuai dengan habitat hidup alga, penyerapan nutrien dan air berjalan dengan baik maka pertumbuhan dan perkembangan sel akan berjalan dengan baik. Pertumbuhan dan perkembangan eksplan yang lambat disebabkan penyerapan nutrien tidak optimal karena kondisi media kultur tidak sesuai untuk pertumbuhan. Kondisi media kultur yang tidak sesuai dapat mengganggu kerja enzim dan turunnya tekanan turgor di dalam sel dan menghambat pembelahan sel. Salinitas mempengaruhi mekanisme fisiologi dan biokimia terutama tekanan osmosis yang berkaitan erat dengan peran membran sel dalam proses transport nutrien dan memberikan efek stimulasi terhadap pertumbuhan rumput laut (Yokoya et al., 1999; Rumampuk et al., 2004; Hurtado-Ponce et al., 2009; Luhan dan Sollesta, 2010).

\section{Kualitas air}

Kandungan nitrit di perairan berada pada kisaran 0-0,03 mg. $\mathrm{L}^{-1}$, nitrat berada pada kisaran 0,06-0,25 mg. $\mathrm{L}^{-1}$ dan fosfat berada pada kisaran 0,12-0,33, kondisi ini masih layak untuk mendukung kegiatan budidaya. Gambar 7. Kadar nitrit di perairan secara alami berada pada kisaran 0,001 mg.L-1 dan sebaiknya tidak melebihi 0,05 mg. $\mathrm{L}^{-1}$ karena dapat bersifat toksik bagi organisme perairan. Batas toleransi nitrat terendah untuk pertumbuhan alga adalah 0,1-3 mg.t-1 dan kandungan fosfat dalam perairan pada kisaran 0,051-0,2 mg.t-1 digolongkan dalam kategori kesuburan tinggi (Moore, 1991; Effendi, 2003). 
Suhu dan salinitas perairan disajikan pada Gambar 8. Suhu berada pada kisaran $26-29^{\circ} \mathrm{C}$, salinitas air berada pada kisaran 2-16 ppt. Salinitas terendah diperoleh pada awal penelitian (bulan Februari), hal ini disebabkan karena pada bulan Februari merupakan masa peralihan dari musim hujan ke kemarau, sehingga bulan tersebut kadang-kadang masih terjadi hujan yang mengakibatkan salinitas air rendah. Pada salinitas tersebut rumput laut $G$. verrucosa masih dapat tumbuh. Menurut Choi et al. (2006) suhu terbaik untuk pertumbuhan spesies G. verrucosa pada kisaran $17-30{ }^{\circ} \mathrm{C}$ dan $\mathrm{G}$. verrucosa dapat tumbuh pada kisaran salinitas yang lebar, yakni 5-35 ppt, dan tumbuh baik baik pada kisaran
15-30 ppt. Secara umum kondisi lingkungan perairan tambak masih layak untuk kegiatan budidaya. Lingkungan yang sesuai untuk eksplan hasil kultur jaringan sangat menentukan arah pertumbuhan dan berkembangannya menjadi tumbuhan dewasa.

Proses aklimatisasi bagian dari rangkaian proses bioteknologi, merupakan proses adaptasi eksplan dengan lingkungan budidaya. Keberhasilan eksplan dalam beradaptasi dengan lingkungan budidaya merupakan kunci keberhasilan produksi masal bibit rumput laut hasil kultur jaringan (Rorrer dan Cheney, 2004; Yong et al., 2014). Dari

\begin{tabular}{|c|c|c|c|c|c|}
\hline \multirow{2}{*}{ Spesies } & \multicolumn{5}{|c|}{ Lama pemeliharaan } \\
\hline & Awal & 15 hari & 30 hari & 45 hari & 60 hari \\
\hline \multicolumn{6}{|l|}{ G. verrucosa } \\
\hline G. gigas & & & & & \\
\hline
\end{tabular}

Gambar 6. Perkembangan eksplan G. verrucosa dan G. gigas selama aklimatisasi di tambak

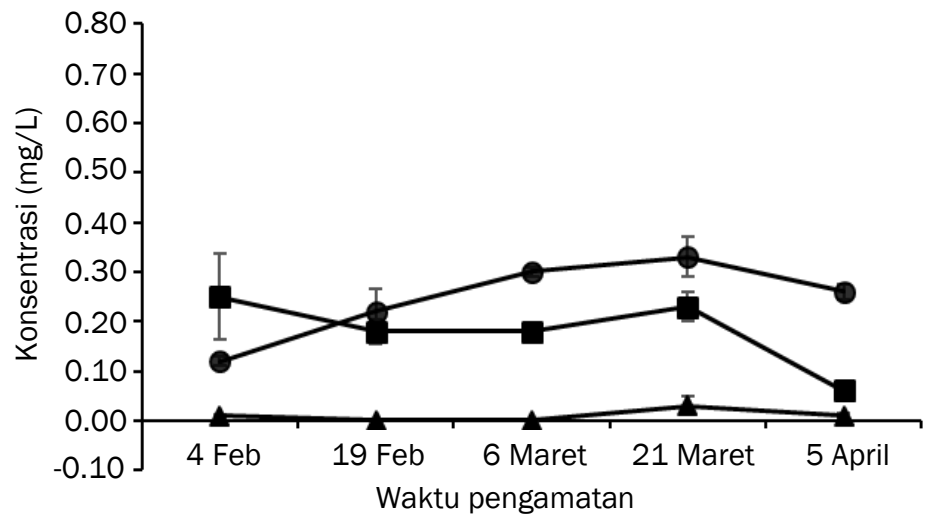

Gambar 7. Kandungan nutrien perairan selama penelitian; $-\triangle-\mathrm{NO}_{2},-\rightarrow-=\mathrm{PO}_{4},-\square-=\mathrm{NO}_{3}$

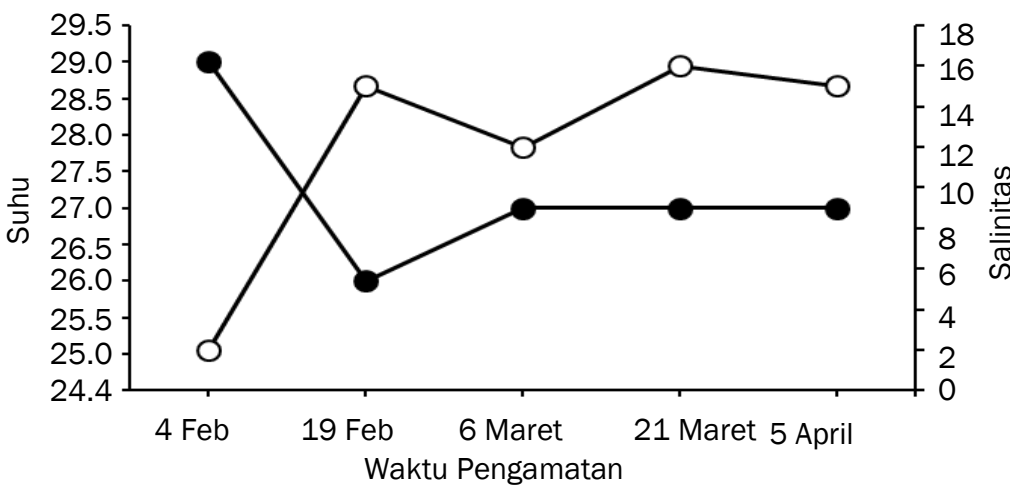

Gambar 8. Suhu dan salinitas perairan selama penelitian; $-\mathbf{-}=$ = suhu, $-\mathbf{O}-\mathbf{-}=$ salinitas 
Tabel 1. Penampang melintang sel medula talus rumput laut G. verrucosa (skala bar=2 $\mu \mathrm{m})$ dan $\mathrm{G}$. gigas $(\mathrm{skala}$ bar $=5 \mu \mathrm{m})$.

\begin{tabular}{|c|c|c|}
\hline Spesies & Irisan melintang sel & Keterangan \\
\hline G. verrucosa & 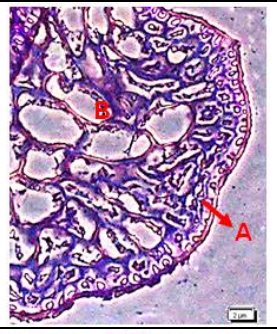 & $\begin{array}{l}A=\text { Korteks } \\
B=\text { Medula }\end{array}$ \\
\hline G. gigas & & $\begin{array}{l}A=\text { Korteks } \\
B=\text { Medula }\end{array}$ \\
\hline
\end{tabular}

penelitian diperoleh informasi bahwa rumput laut $G$. verrucosa dapat beradaptasi dengan lingkungan budidaya tambak lebih baik daripada G. gigas, sehingga peluang produksi massal bibit rumput laut G. verrucosa hasil kultur jaringan di tambak lebih besar daripada rumput laut G. gigas.

\section{Kesimpulan}

Pada budidaya di tambak, rumput laut $G$. verrucosa memiliki pertumbuhan yang berbeda nyata dengan $G$. gigas $(P<0,05)$. Rumput laut $G$. verrucosa memiliki LPH bobot lebih tinggi $(3,27 \%)$ dari G. gigas (2\%) dan LPH panjang lebih tinggi dari G. gigas, masing-masing sebesar 3,06\% dan 2,18\%. Faktor fisika dan kimia lingkungan perairan tambak kurang sesuai untuk pertumbuhan rumput laut $G$. gigas yang memiliki susunan sel korteks yang lebih rapat daripada G. verrucosa, sehingga pada budidaya di tambak perkembangan eksplan rumput laut G. verrucosa lebih baik daripada G. gigas.

\section{Daftar Pustaka}

Anggadiredja, J.T., A. Zatnika, H. Purwoto \& S. Istini. 2007. Rumput Laut. Penebar Swadaya. Jakarta. 152 hal.

Bixler, H.J. \& H. Porse. 2011. A decade of change in the seaweed hydrocolloids industry. J. Appl. Phycol. 23:321-335. doi:10.1007/s10811-01 0-9529-3.

Choi, H.G., Y.S. Kim, J.H. Kim, S.J. Lee, E.J. Park, J. Ryu \& K.W. Nam. 2006. Effect of temperature and salinity on the growth of Gracilaria verrucosa and $G$. chorda, with the potential for mariculture in Korea. J. Appl. Phycol. 18:269277. doi:10.1007/s 10811-006-9033-y.

Choi, T.S., E.J. Kang, J.H. Kim \& K.Y. Kim. 2010. Effect of salinity on growth and nutrient uptake of Ulva pertusa (Chlorophyta) from an eelgrassbed. Algae 25(1):17-25. doi:10.4490 /algae.2010.25.1.017.

Dawes, C.J. 1981. Marine Botany. John Wiley \& Sons, Inc.628 pp.

Dawes, C.J., C. Kovach \& M. Friedlander.1993. Exposure of Gracilaria to various environmental conditions II.The effect on fatty acid composition. Bot. Mar. 36:289-296. doi:10.15 15/botm.1993.36.4.289.

Diana, F., K. Nirmala \& D.T. Soelistyawati. 2014. Analisis Kualitas Rumput Laut Gracilaria gigas Yang Dibudidayakan Pada Habitat Laut dan Tambak, Nusa Tenggara Barat. J. Riset Akuakul. 9(1):59-65.

Effendi, H. 2003. Telaah Kualitas Air: Bagi Pengelolaan Sumber Daya dan Lingkungan Perairan. Kanisius. Yogyakarta. 257 hal.

FAO. 2012. The State Of World Fisheries and Aquaculture 2012. Rome. 209 pp.

FAO. 2014. The State of World Fisheries and Aquaculture 2014. Rome. 223 pp.

Hurtado-Ponce, A.Q. 1990. Verticl rope cultivation of Gracilaria (Rhodophyta) using vegetative fragments. Bot. Mar. 33:477-482. doi:10.15 15/botm.1990.33.6.477.

Hurtado-Ponce, A.Q., D.A. Yunque, K. Tibubos \& A.T. Critchley. 2009. Use of Acadian Marine Plant 
Extract Powder from Ascophyllum nodosum in Tissue Culture of Kappaphycus alvarezii. J.Appl. Phycol. 21:633-639. doi:10.1007/s10811-00 8-9395-4.

Kadi, A. \& W. S. Atmadja. 1988. Rumput laut (Algae): jenis, reproduksi, produksi, budidaya dan pasca panen. Puslitbang Oseanografi, LIPI, Jakarta, 71 hal.

Lobban, C.S. \& P.J. Harrison. 1994. Seaweed Ecology and Physiology. Cambridges University Press. 366 pp.

Luhan, M.R.J. \& H. Sollesta. 2010. Growing the reproductive cells (carpospores) of the seaweed, Kappaphycus striatum, in the laboratory until outplanting in the field and maturation to tetrasporophyte. J. Appl Phycol. 22:579-585. doi:10.1007/s10811-00994977.

Lüning, K. \& S. Pang. 2003. Mass cultivation of seaweeds: current aspects and approaches. J. Appl. Phycol. 15:115-119. doi:10.1023/A:10 23807503255.

Moore, J.W. 1991. Inorganic Contaminants of Surface Water Research and Monitoring Priorities. Springer-Verlag. New York. 334 p.

Mulyaningrum, S.R.H., R. Daud \& Badraeni. 2014. Propagasi Vegetatif Rumput Laut Gracilaria sp Melalui Kultur Jaringan. J. Riset Akuakul. 4(2): 203-214.

Ohmi, H. 1958. The species of Gracilaria and Gracilariopsis from Japan and adjacent waters. Memoirs Fac. Fisheries Hokkaido Univ. 6(1):166.

Ortega, J.K.E. 2010. Plant Cell Growth in Tissue. Plant Physiol. 154:1244-1253. doi:10.1104/ pp.110.162644.

Reddy, C.R.K., B. Jha, Y. Fujita \& M. Ohno. 2008. Seaweed micropropagation techniques and their potentials: an overview. J. Appl Phycol. 20: 609-617. doi:10.1007/s 10811-007-9205-4.

Ren, G.Z., J.G. Wang \& M.G. Chen. 1984. Cultivation of Gracilaria by means of low rafts. Hydrobiologia. 116(117):72-76. doi:10.1007/ BF00027642.

Rorrer, G.L. \& D.P. Cheney. 2004. Bioprocess engineering of cell and tissue cultures for marine seaweeds. Aquacult. Engineering. 32: 11-41. doi:10.1016/j.aquaeng.2004. 03.007.
Rueness, J. \& T. Tananger. 1984. Growth in culture of four red algae from Norway with potential for mariculture. Hydrobiologia. 116(117):303307. doi: 10.1007/BF00027690.

Rumampuk, N.D.C., G.S. Grevo, I.F.M. Rumengan, M. Ohji, T. Arai \& N. Miyazaki. 2004. Effect of Triphenyltin Exposure on The Red Alga Eucheuma denticulatum. Coast. Mar. Sci. 29 (1):81-84.

Skurzynski, P. \& K. Bocia. 2011.Vegetative propagation of Chara rudis (Characeae, Chlorophyta). Phycologia. 50(2):194-201. doi: 10.2216/09-64.1.

Terada, R. \& M. Ohno. 2000. Notes on Gracilaria (Gracilariales, Rhodophyta) from Tosa Bay and adjacent waters I: Gracilaria chorda, Gracilaria gigas and Gracilaria incurvata. Bull. Mar. Sci. Fish. 20:81-88.

Yokoya, N.S., E.M. Plastino \& R. Artel. 2003. Physiological responses and pigment characterization of two colour strains of the carrageenophyte Hypnea musciformis (Rhodophyta). Proc. 17th Int. Seaweed Symposium: 425-434.

Yokoya, N.S., H. Kakita, H. Obika \& T. Kitamura. 1999. Effect of environmental factors and plant growth regulators on growth of the red alga Gracilaria vermiculophylla from Shikoku Island, Japan. Hydrobiologia. 398/399:339-347. doi: 10.1023/A:1017072508583.

Yong, W.T.L., S.H. Ting, Y.S. Yong, V.Y. Thien, S.H. Wong, W.L. Chin, K.F. Rodrigues \& A. Anton. 2013. Optimization of culture conditions for the direct regeneration of Kappaphycus alvarezii (Rhodophyta, Solieriaceae). J. Appl Phycol. 25(5):1597-1606. doi:10.1007/s 10811-0130191-4.

Yong, Y.S., W.T.L. Yong, V.Y. Thien, S.E. Ng, A. Anton \& S. Yassir. 2014. Acclimatization of micropropagated Kappaphycus alvarezii (Doty)Doty ex Silva (Rhodophyta, Solieriaceae) in outdoor nursery system. J. Appl. Phycol. 26(1): 1-7. doi:10.1007/s10811-014-0289-3

Yudiati, E., E.S. Susilo \& C.A. Suryono. 2004. Teknik Setting Spora Gracilaria gigas Sebagai Penyedia Benih Unggul dalam Budidaya Rumput Laut. IImu Kelautan. 9(1):37-40. 